\title{
Staphylococcus gallinarum and Staphylococcus caprae, Two New Species from Animals
}

\author{
L. A. DEVRIESE, ${ }^{1 *}$ B. POUTREL,${ }^{2}$ R. KILPPER-BÄLZ, ${ }^{3}$ AND K. H. SCHLEIFER ${ }^{3}$ \\ Faculty of Veterinary Medicine, University of Ghent, Casinoplein 24, B-9000 Ghent, Belgium ${ }^{1}$; Station de \\ Pathologie de la Reproduction, I.N.R.A., F-37380 Nouzilly, France ${ }^{2}$; and Lehrstuhl Microbiologie, \\ Technische Universität, München, D-8000 Munich 2, Federal Republic of Germany ${ }^{3}$
}

We describe a new species, Staphylococcus gallinarum, based on a study of characteristics of strains isolated from chickens and a pheasant. Strain CCM 3572 $\left(=\mathrm{VIII}_{1}\right)$ is the type strain of this species. The chemical composition of the cell walls of the strains of this new species is similar to that of Staphylococcus epidermidis, but these organisms are resistant to novobiocin and produce acid from a wide range of carbohydrates. Staphylococcal strains isolated from goat milk belong to another new species, Staphylococcus caprae. The type strain is CCM $3573(=143.22)$. These strains are more closely related to $S$. epidermidis and Staphylococcus capitis than to other staphylococci.

In 1975 Kloos and Schleifer $(18,19,28)$ presented a new classification of the genus Staphylococcus which included descriptions of several novel species. This system, which was originally based on a study of strains isolated from humans, was later extended to include descriptions of new species from animals $(8,15,20)$ and various other sources $(24,27)$. Also, the anaerobic organism Peptococcus saccharolyticus was shown to belong to the genus Staphylococcus (16).

During studies on the characteristics of Staphylococcus strains isolated from the skin of poultry and goat milk, two groups which could not be grouped with the known named species or unnamed groups were discovered (21).

\section{MATERIALS AND METHODS}

Strains. An initial group of poultry strains (strains $\mathrm{VIII}_{1}[=\mathrm{CCM} 3572], \mathrm{VIII}_{31}, \mathrm{VIII}_{32}, \mathrm{VIII}_{38}, \mathrm{VIII}_{41}$, $\mathrm{VIII}_{43}, \mathrm{VIII}_{45}, \mathrm{VIII}_{49}, \mathrm{VIII}_{52}$, and $\mathrm{VIII}_{53}$ were isolated in 1973. A second group (strains $P_{9}, P_{21}, P_{37}$, and $P_{57}$ ) were isolated in 1976. All strains except one originated from the nares or skin of chickens from Belgium. Strain $\mathrm{P}_{57}$ was recovered from the conjunctiva of a pheasant.

Goat strains 143.22 (= CCM 3573), 143.21, 143.17, $143.16,143.15,143.13,143.11$, and 143.6 were isolated from milk samples taken from different goats in the same herd in France. Strains 142.25 and 141.15 were obtained from two other herds.

These strains were compared with several staphylococcal type strains (see Table 2), which were obtained from the American Type Culture Collection (ATCC), Rockville, Md., the Deutsche Sammlung von Mikroorganismen (DSM), Göttingen, Federal Republic of Germany, the Czechoslovak Collection of Microorganisms (CCM), Brno, Czechoslovakia, and W. E. Kloos, North Carolina State University, Raleigh.
Methods. The following characteristics were determined as described previously: clumping factor (7); anaerobic growth in semisolid Brewer thioglycolate medium (11); oxidase (12); heat-stable nuclease (9); heat-labile nuclease (9); staphylokinase (10); reduction of nitrate (19); hydrolysis of polysorbate (Tween 80) (6); gelatin (13); casein (7); arginine (7); and phosphatase (7).

The tube coagulase test was carried out with rabbit plasma (Coagulase plasma; Difco Laboratories, Detroit, Mich.) according to the instructions provided by the manufacturer. Hemolytic activity was tested on blood agar base (Oxoid, Basingstoke, England) supplemented with $5 \%$ sheep or human blood. Hyaluronidase was determined on tryptose agar (Difco) supplemented with $5 \%$ inactivated horse serum by using a Pasteurella multocida capsule type A strain as a source of hyaluronic acid. Urease activity was tested on Christensen urea agar (Oxoid) and in a medium containing (per liter) $10 \mathrm{mg}$ of $\mathrm{KH}_{2} \mathrm{PO}_{4}, 10 \mathrm{mg}$ of $\mathrm{K}_{2} \mathrm{HPO}_{4}, 50 \mathrm{mg}$ of $\mathrm{NaCl}, 10 \mathrm{mg}$ of phenol red, and $20 \mathrm{~g}$ of urea (22). Esculin hydrolysis was read after 2 days of incubation of esculin bile agar (Oxoid). Motility was examined by the hanging drop method. Acid production from carbohydrates was tested in phenol red broth (GIBCO, Paisley, Scotland) supplemented with sugars at concentrations of $1 \%$ (the sugars were added from filter-sterilized solutions). Production of acetoin from glucose was determined by the method of Davis and Hoyling (5). The same test was repeated with pyruvate as a substrate, using the API Staph medium and reagents (API Systems, La Balme les Grottes, France), as described by Bornstein and Fleurette (3). The minimal inhibitory concentrations (MICs) of various antibiotics, lysostaphin (Becton, Dickinson \& Co., Cockeysville, Md.), and egg white lysozyme (grade I; Sigma Chemical Co., St. Louis, Mo.) were determined by the agar dilution technique, using overnight broth cultures diluted 100 -fold as inocula and tryptone soya agar (Oxoid) or diagnostic sensitivity test agar (Oxoid) as the test medium. The MICs were compared with the 
MICs for Staphylococcus aureus ATCC 25923 without acquired resistance.

Cell walls were prepared and the peptidoglycan type was determined as described by Schleifer and Kandler $(25,26)$. The compositions of cell wall teichoic acids were determined as previously described (27). The procedure used for determining the configurations of the lactic acids produced has also been described previously $(28,29)$. The guanine-plus-cytosine contents of deoxyribonucleic acids (DNAs) were determined by the thermal denaturation method of Marmur and Doty (23). The DNA-DNA hybridization experiments were performed as described previously (16, 30). Fructose 1,6-diphosphate aldolase classes were determined by the method of Götz et al. (14).

\section{RESULTS AND DISCUSSION}

Poultry strains: description of Staphylococcus gallinarum sp. nov. Based on the test results obtained with the 14 strains isolated from poultry, a new species, Staphylococcus gallinarum (gal. li. na' rum. L. fem. n. gallina hen; L. fem, gen. pl. n. gallinarum of hens), can be described as follows. Cells are nonsporulating, nonmotile, gram-positive cocci 0.5 to $1.8 \mu \mathrm{m}$ in diameter (median, $1.1 \mu \mathrm{m}$ ) and occur singly, in pairs, or in small groups or chains composed of 3 to 10 cells.

Eleven strains produce remarkably large colonies with lobate or crenate edges. Most wellseparated colonies are 10 to $15 \mathrm{~mm}$ in diameter on brain heart infusion agar (Oxoid) or 5 to 10 $\mathrm{mm}$ in diameter on tryptone soya agar (Oxoid) after 2 days of incubation. However, growth is highly variable, with outgrowths measuring up to $40 \mathrm{~mm}$ at times. Sometimes these lobed outgrowths differ in pigmentation from the parent colonies. The colonies are opaque and flat and have dry surfaces. Strain VIII $_{53}$ produces raised glistening colonies with flattened outgrowths. The strains dissociate into a smaller colony type (colony diameter, 4 to $7 \mathrm{~mm}$ ) after 2 days on brain heart infusion agar; these colonies have entire edges and smooth glistening surfaces. This is most easily demonstrated with strains $\mathrm{VIII}_{1}$ and $\mathrm{P}_{21}$. Three strains (strain $\mathrm{VIII}_{38}, \mathrm{VIII}_{52}$, and $\mathrm{P}_{57}$ ) appeared on the primary isolation plates only as the smaller colony type, and they maintained this form during repeated subcultures. Three strains (strains $\mathrm{VIII}_{41}$, $\mathrm{VIII}_{52}$, and $\mathrm{P}_{21}$ ) are not pigmented; the others are yellow or have a yellowish tint. In nutrient broth uniform turbidity with small deposits is observed after overnight incubation. The strains grow well at $25,30,37$, and $42^{\circ} \mathrm{C}$, but colonies are smaller after 24 or $48 \mathrm{~h}$ at $25^{\circ} \mathrm{C}$ than at 30,37 , or $42^{\circ} \mathrm{C}$.

All strains produce class I fructose 1,6-diphosphate aldolases. They are able to grow aerobically and anaerobically. However, anaerobic colonies in semisolid thioglycolate medium are smaller than aerobic colonies. The $\mathrm{pH}$ of a peptone-yeast extract-glucose broth is lowered from 6.8 to 4.6 to 5.1 after 2 days of anaerobic growth. Predominantly L-lactic acid is produced.

The results of biochemical tests are shown in Table 1.

All strains contain peptidoglycan of type LLys-Gly $_{4-5}, \mathbf{L}-\mathrm{Ser}_{0.7-1.0}$. The cell wall teichoic acids of the strains are composed of glycerol, glucose, and small amounts of $\mathrm{N}$-acetylglucosamine.

All strains are resistant to novobiocin (MIC, 4 to $32 \mu \mathrm{g} / \mathrm{ml}$ ) and lysozyme (MIC, $>800 \mu \mathrm{g} / \mathrm{ml}$ ). The lysostaphin MICs are 34 to $64 \mu \mathrm{g} / \mathrm{ml}$. The levels of susceptibility to the following antibiotics are higher than the levels normally found for $S$. aureus: penicillin G (MIC, 0.1 to $0.5 \mu \mathrm{g} / \mathrm{ml}$ ), cloxacillin (MIC, 1 to $2 \mu \mathrm{g} / \mathrm{ml}$ ), erythromycin (MIC for most strains, 0.5 to $1 \mu \mathrm{g} / \mathrm{ml}$; the exceptions are strains $\mathrm{VIII}_{1}, \mathrm{VIII}_{43}, \mathrm{VIII}_{49}$, and $\mathrm{P}_{57}$, which have MICs of $>128 \mu \mathrm{g} / \mathrm{ml}$ ), and lincomycin (MIC for all strains except one, 2 to 8 $\mu \mathrm{g} / \mathrm{ml}$; strain VIII $_{1}$ has a lincomycin MIC of $>128 \mu \mathrm{g} / \mathrm{m}$ ). All strains are susceptible to neomycin (MIC, 0.06 to $0.25 \mu \mathrm{g} / \mathrm{ml}$ ), sulfonamides (sodium sulfamethoxazole MIC, 4 to $32 \mu \mathrm{g} / \mathrm{ml}$ ), and chloramphenicol (MIC, 4 to $16 \mu \mathrm{g} / \mathrm{ml}$ ). Most strains show acquired resistance to tetracyclines (tetracycline hydrocholoride MIC, 32 to 128 $\mu \mathrm{g} / \mathrm{ml})$. Only strains $P_{9}$ and $P_{21}$ are susceptible to tetracycline (MIC, $0.5 \mu \mathrm{g} / \mathrm{ml}$ ). Strains VIII $_{1}$ and $\mathrm{VIII}_{49}$ are resistant to streptomycin (MIC, $>128$ $\mu \mathrm{g} / \mathrm{ml}$ ); the other strains are inhibited at streptomycin concentrations of 2 to $4 \mu \mathrm{g} / \mathrm{ml}$. The levels of susceptibility to nitrofurazolidone are bimodally distributed; the furazolidone MICs for the more susceptible strains are 1 to $2 \mu \mathrm{g} / \mathrm{ml}$, whereas strains $\mathrm{VIII}_{1}, \mathrm{VIII}_{32}, \mathrm{VIII}_{41}, \mathrm{VIII}_{43}, \mathrm{VIII}_{45}$, VIII $_{49}$, and $P_{21}$ are only inhibited at a concentration of $8 \mu \mathrm{g} / \mathrm{ml}$. This low level of resistance to nitrofurans has not been reported previously in Staphylococcus strains. This resistance level is lower than that for Micrococcus strains (4), and thus nitrofuran susceptibility still can be used to distinguish these strains from Micrococcus species, as has been proposed by Curry and Borovian (4) and von Rheinbaben and Hadlok (31).

DNA-DNA hybridization studies indicated that the strains of $S$. gallinarum are closely related, whereas the levels of DNA homology with other staphylococci are rather low (10 to $25 \%$ ); nevertheless, these levels are significantly higher than the levels obtained when staphylococci and Streptococcus faecalis are compared (Table 2).

$S$. gallinarum is easily differentiated from the novobiocin-resistant organisms Staphylococcus saprophyticus, Staphylococcus cohnii, and Staphylococcus xylosus by its wide range of positive carbohydrate reactions. None of these 
TABLE 1. Characteristics of $14 S$. gallinarum strains

\begin{tabular}{|c|c|}
\hline Test & $\begin{array}{l}\text { No. of } \\
\text { strains } \\
\text { positive }\end{array}$ \\
\hline \multicolumn{2}{|l|}{ Anaerobic growth in semisolid thioglycolate } \\
\hline Hemolysis on sheep blood agar (after 2 days) ${ }^{a}$ & $8^{b}$ \\
\hline 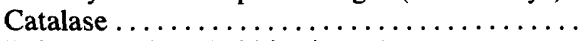 & 14 \\
\hline Tube coagulase (rabbit plasma)........... & 0 \\
\hline Clumping factor (rabbit plasma) .......... & 0 \\
\hline stable nuclease $\ldots \ldots \ldots \ldots \ldots \ldots \ldots$ & 0 \\
\hline Oxidase $\ldots \ldots \ldots \ldots \ldots \ldots \ldots \ldots \ldots \ldots \ldots$ & 0 \\
\hline Phosphatase $\ldots \ldots \ldots \ldots \ldots \ldots \ldots \ldots$ & 14 \\
\hline$\ldots \ldots \ldots \ldots \ldots \ldots \ldots \ldots$ & 14 \\
\hline of casein ${ }^{a} \ldots \ldots$ & 14 \\
\hline polysorbate (Tween 80$) \ldots . . \ldots$ & 0 \\
\hline yruvate and glucose ........ & 0 \\
\hline & 0 \\
\hline & 0 \\
\hline sculin $\ldots \ldots \ldots \ldots \ldots \ldots \ldots$ & 14 \\
\hline Hydrolysis of urea $\ldots \ldots \ldots \ldots \ldots \ldots \ldots$ & $13^{c}$ \\
\hline \multicolumn{2}{|l|}{ Production of acid from: } \\
\hline Amygdalin .......... & $13^{d}$ \\
\hline & 14 \\
\hline & 14 \\
\hline$\ldots \ldots \ldots \ldots \ldots \ldots \ldots \ldots$ & $13^{e}$ \\
\hline$\ldots \ldots \ldots \ldots \ldots \ldots \ldots \ldots \ldots$ & 14 \\
\hline D-Fuco & \\
\hline$\ldots \ldots$ & 14 \\
\hline$\beta-G$ & 14 \\
\hline & $12^{f}$ \\
\hline cha & 14 \\
\hline Lact & $10^{g}$ \\
\hline Malt & 14 \\
\hline D-Mar & $13^{h}$ \\
\hline $\mathrm{D}-\mathrm{Ma}$ & 14 \\
\hline Mele & 14 \\
\hline Melibios & 14 \\
\hline Raffino & 14 \\
\hline L-Rhat & $1^{i}$ \\
\hline D-Ril & 14 \\
\hline Salicin. . . . . . . & $13^{j}$ \\
\hline Sucr & 14 \\
\hline Treha & 14 \\
\hline Turar & 14 \\
\hline Xylit & $10^{k}$ \\
\hline D-Xy & 14 \\
\hline
\end{tabular}

${ }^{a}$ Many weak reactions.

${ }^{b}$ Negative strains: $\mathrm{VIII}_{1}{ }^{\mathrm{T}}, \mathrm{VIII}_{31}, \mathrm{VIII}_{38}, \mathrm{VIII}_{43}$, $\mathrm{VIII}_{45}$, and $\mathrm{VIII}_{52}$.

${ }^{c}$ Negative strain: VIII $_{41}$.

${ }^{d}$ Negative strain: VIII $_{38}$.

${ }^{e}$ Negative strain: $\mathrm{VIII}_{52}$.

${ }^{f}$ Negative strains: $\mathrm{VIII}_{38}$ and $\mathrm{VIII}_{53}$.

${ }^{8}$ Negative strains: $\mathrm{VIII}_{45}, \mathrm{P}_{9}, \mathrm{P}_{21}$, and $\mathrm{P}_{37}$.

${ }^{h}$ Negative strain: VIII $_{53}$.

${ }^{i}$ Positive strain: VIII $_{41}$.

${ }^{j}$ Negative strain: VIII $_{38}$.

${ }^{k}$ Negative strains: VIII $_{1}{ }^{\mathrm{T}}, \mathrm{VIII}_{53}, \mathrm{P}_{9}$, and $\mathrm{P}_{21}$.

other species produces acid from fucose, cellobiose, melezitose, and raffinose (20), but $S$. gallinarum does. Also, the very irregular colony morphology with strongly crenate edges is a useful diagnostic trait; this characteristic is found only in $S$. gallinarum and certain $S$. xylosus strains. In particular, strains which produce only colonies with entire edges can be confused with Staphylococcus sciuri subsp. lentus. The ability of these organisms to grow anaerobically in thioglycolate shake cultures, their positive urease reactions, and their negative oxidase reactions are useful distinguishing characteristics. However, it is important to use the highly sensitive oxidase test described by Faller and Schleifer (12).

Strain VIII $_{1}$ (= CCM 3572) is the type strain of $S$. gallinarum. This strain was isolated from the nares of a chicken and a description of it is given below.

Strain VIII $_{1}$ cells are gram-positive cocci and are usually about $1 \mu \mathrm{m}$ in diameter. In broth these cells occur singly, in pairs, or in small groups or chains; the cells are nonmotile and nonsporeforming.

Two colony forms occur; most colonies have dry surfaces and very pronounced crenate edges. Well-separated colonies are 5 to $15 \mathrm{~mm}$ in diameter after 2 days, but larger outgrowths may occur. Other colonies are smaller and have glistening surfaces and entire edges. A yellowish or creamy pigment is produced.

Broth cultures are uniformly turbid, with a small deposit. Growth at $25^{\circ} \mathrm{C}$ is slower than growth at 30,37 , and $42^{\circ} \mathrm{C}$. Facultatively anaerobic.

In addition to the negative and positive biochemical characteristics listed in Table 1 , the following reactions occur: weakly hemolytic in sheep blood agar after 2 days of incubation; proteolytic on casein; urease positive; and acid produced from amygdalin, cellobiose, lactose, mannitol, salicin, and glucitol. No acid is produced from xylitol and rhamnose.

The antibiotic susceptibilities of strain VIII ${ }^{\mathrm{T}}$ are as follows: resistant to novobiocin, tetracycline hydrochloride, streptomycin, erythromycin, and lincomycin; low-level resistance to penicillin G, cloxacillin, and furazolidone; and susceptible to neomycin, sulfamethoxazole, and chloramphenicol. Erythromycin resistance, lincomycin resistance, tetracycline resistance, streptomycin resistance, and furazolidone resistance are probably due to acquired resistance determinants and are not representative for the species.

Lysostaphin MIC: $64 \mu \mathrm{g} / \mathrm{ml}$. Resistant to lysozyme.

Class I fructose 1,6-diphosphate aldolase.

Peptidoglycan type: L-Lys-Gly ${ }_{4-5}, \mathrm{~L}-\mathrm{Ser}_{0.8}$.

Composition of cell wall teichoic acid: glycerol, glucose, and small amounts of $N$-acetylglucosamine. 
TABLE 2. DNA-DNA hybridization relationships among strains of $S$. gallinarum, $S$. caprae, and various other staphylococci

\begin{tabular}{|c|c|c|c|c|c|c|c|c|c|c|}
\hline \multirow{3}{*}{ Source of filter-bound DNA } & \multicolumn{10}{|c|}{$\%$ Relative binding of labeled DNA from: } \\
\hline & \multicolumn{4}{|c|}{ S. gallinarum } & \multicolumn{2}{|c|}{ S. caprae } & \multirow{2}{*}{$\begin{array}{c}\text { Staphy- } \\
\text { lococcus } \\
\text { xylosus } \\
\text { DSM } \\
20266^{\mathrm{T}}\end{array}$} & \multirow{2}{*}{$\begin{array}{l}\text { Staphy- } \\
\text { lococcus } \\
\text { sapro- } \\
\text { phyticus } \\
\mathrm{KL}_{150^{\mathrm{T}}}\end{array}$} & \multirow{2}{*}{$\begin{array}{c}\text { Staphylo- } \\
\text { coccus } \\
\text { epider- } \\
\text { midis } \\
\text { ATCC } \\
14990^{\mathrm{T}}\end{array}$} & \multirow{2}{*}{$\begin{array}{c}\text { Staphy- } \\
\text { lococcus } \\
\text { aureus } \\
\text { ATCC } \\
12600^{\mathrm{T}}\end{array}$} \\
\hline & $\begin{array}{l}\text { CCM } \\
3572^{\mathrm{T}}\end{array}$ & $P_{57}$ & VIII $_{49}$ & VIII $_{38}$ & $\begin{array}{l}\mathrm{CCM} \\
3573^{\mathrm{T}}\end{array}$ & 141.15 & & & & \\
\hline S. gallinarum CCM $3572^{T}$ & 100 & 87 & 100 & 89 & 17 & & 27 & 30 & 19 & 24 \\
\hline S. gallinarum $\mathrm{P}_{57}$ & 83 & 100 & 90 & 88 & 18 & & 31 & & & \\
\hline S. gallinarum $\mathrm{VIII}_{45}$ & 76 & 77 & & & & & 28 & & & \\
\hline S. gallinarum $\mathrm{VIII}_{49}$ & 100 & 96 & 100 & 83 & & & 25 & & & \\
\hline S. gallinarum $\mathrm{VIII}_{38}$ & 77 & 82 & 79 & 100 & & & 25 & & & \\
\hline S. gallinarum $\mathrm{VIII}_{43}$ & 84 & 72 & & & & & 26 & & & \\
\hline S. gallinarum VIII 52 & 77 & 77 & & & & & 24 & & & \\
\hline S. gallinarum $\mathrm{P}_{21}$ & 80 & 76 & & & & & 26 & 27 & 15 & 25 \\
\hline S. caprae CCM $3573^{\mathrm{T}}$ & & & & & 100 & 83 & & & 33 & 25 \\
\hline$S$. caprae 141.15 & & & & & 87 & 100 & & & 33 & 26 \\
\hline $\begin{array}{l}\text { Staphylococcus xylosus } \\
\text { DSM } 20266\end{array}$ & 25 & 23 & 22 & 27 & 16 & 15 & 100 & & 18 & 24 \\
\hline $\begin{array}{l}\text { Staphylococcus cohnii DSM } \\
20260^{\mathrm{T}}\end{array}$ & 22 & & & & 16 & 18 & 21 & 33 & 20 & 23 \\
\hline $\begin{array}{l}\text { Staphylococcus haemolyti- } \\
\text { cus DSM } 20263^{\mathrm{T}}\end{array}$ & 21 & & & & 25 & 21 & 26 & & & \\
\hline 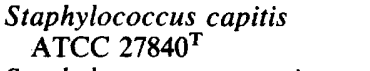 & 21 & & & & 36 & 35 & 22 & 23 & & \\
\hline $\begin{array}{l}\text { Staphylococcus warneri } \\
\text { ATCC } 27836^{\mathrm{T}}\end{array}$ & 19 & & & & & 20 & 23 & 24 & & \\
\hline $\begin{array}{l}\text { Staphylococcus epidermidis } \\
\text { ATCC } 14990\end{array}$ & 21 & & & & 32 & 31 & 19 & & 100 & \\
\hline $\begin{array}{l}\text { Staphylococcus aureus } \\
\text { ATCC } 12600\end{array}$ & 19 & & & & 24 & 22 & 21 & 23 & 24 & 100 \\
\hline $\begin{array}{l}\text { Staphylococcus saccharoly- } \\
\text { ticus DSM } 20359\end{array}$ & 14 & & & & 27 & 24 & 18 & & & \\
\hline $\begin{array}{l}\text { Staphylococcus simulans } \\
\text { ATCC } 27848^{\mathrm{T}}\end{array}$ & 17 & & & & 15 & 15 & 17 & 17 & & \\
\hline $\begin{array}{l}\text { Staphylococcus intermedius } \\
\text { CCM } 5739^{\mathrm{T}}\end{array}$ & 13 & & & & 13 & 11 & 17 & 15 & & \\
\hline $\begin{array}{l}\text { Staphylococcus sciuri subsp. } \\
\text { sciuri ATCC } 20062^{\mathrm{T}}\end{array}$ & 12 & & & & & & 13 & 15 & & \\
\hline $\begin{array}{l}\text { Staphylococcus sciuri subsp. } \\
\text { lentus ATCC } 29070^{\mathrm{T}}\end{array}$ & 16 & & & & 15 & 15 & 16 & & 16 & \\
\hline $\begin{array}{l}\text { Staphylococcus caseolyticus } \\
\text { ATCC } 13548^{\mathrm{T}}\end{array}$ & 10 & & & & 9 & 8 & 9 & & 10 & \\
\hline $\begin{array}{l}\text { Streptococcus faecalis DSM } \\
\quad 20478\end{array}$ & 4 & 8 & 7 & 6 & 5 & 6 & 6 & 7 & 5 & 6 \\
\hline
\end{tabular}

${ }^{a}$ From W. E. Kloos, North Carolina State University, Raleigh.

Guanine-plus-cytosine content of DNA: 34.5 mol\% (thermal denaturation method).

Goat strains: description of Staphylococcus caprae sp. nov. Below is a description of the new species Staphylococcus caprae (ca. prae. L. fem. n. capra goat; L. fem. gen. n caprae of a goat), which is associated with goats; this description is based on results obtained with 10 strains isolated from goat milk.

$S$. caprae cells are nonsporulating, nonmotile, gram-positive cocci 0.8 to $1.2 \mu \mathrm{m}$ in diameter and occur singly, in pairs, in short chains, or in small groups. Colonies are circular with entire edges, low convex, opaque, nonpigmented, and glistening. Colony diameters reach 5 to $6 \mathrm{~mm}$ after 2 days on brain heart infusion agar; on tryptose soya agar colonies are 1 to $2 \mathrm{~mm}$ in diameter after 1 day at $37^{\circ} \mathrm{C}$ and 2 to $4 \mathrm{~mm}$ in diameter after 2 days.

All strains grow well aerobically and anaerobically in semisolid thioglycolate medium. They grow equally well at 37 and $45^{\circ} \mathrm{C}$. Growth is slower at $30^{\circ} \mathrm{C}$, and at $25^{\circ} \mathrm{C}$ strong inhibition is evident. Uniform turbidity with a small deposit is produced in nutrient broth. All strains studied produce predominantly L-lactic acid from glu- 
cose under anaerobic growth conditions.

Weak hemolysis is observed irregularly after overnight incubation on sheep blood agar. After 2 days at $37^{\circ} \mathrm{C}$ all strains show a narrow clear hemolysis zone surrounded by a broad zone of faint discoloration. These broad zones become more visible after the plates are kept at $4^{\circ} \mathrm{C}$ in a refrigerator and are reminiscent of the hemolytic effects of $\beta$-hemolysin (sphingomyelinase C), which is produced by many animal $S$. aureus strains and most Staphylococcus intermedius strains. $S$. caprae zones differ from zones produced by $S$. aureus and $S$. intermedius in their delayed appearance and in their diffuse edges. On human blood all $S$. caprae strains produce ony a narrow zone of clear hemolysis, which is visible after incubation for 1 day at $37^{\circ} \mathrm{C}$.

Adegoke and Ojo (2) described four goat strains which possessed similar hemolysis characteristics and were negative for coagulase and clumping factor. It is possible that these strains belong to the same species as our strains. Other goat strains isolated in Nigeria $(1,2)$ differed from these strains by being positive for coagulase, clumping factor, and staphylokinase production or by having negative hemolysis characteristics.

All $S$. caprae strains are negative in the heatstable nuclease test but produce broad reaction zones in deoxyribonuclease plate tests. These zones, which are probably due to a heat-labile nuclease are one to three times the diameters of the inoculation streaks.

Positive results are obtained with all strains in the following biochemical tests: catalase; phosphatase; acetoin production from glucose and pyruvate; nitrate reduction; arginine hydrolysis; and acid production from trehalose, mannose, glycerol, galactose, and lactose. All strains except strain 142.22 are urease positive. Two strains (strains 143.22 and 141.15) are maltose negative. All strains are negative for the following reactions: coagulase with rabbit plasma; clumping factor with rabbit and human plasma; oxidase; protease on casein and gelatin; hyaluronidase; staphylokinase; hydrolysis of polysorbate (Tween 80); and esculin hydrolysis. Acid is not produced from amygdalin, arabinose, arbutin, cellobiose, fructose, fucose, $\beta$ gentiobiose, mannitol, melezitose, melibiose, raffinose, rhamnose, ribose, salicin, glucitol, sucrose, turanose, xylitol, or xylose.

The peptidoglycan type of three strains (strains CCM 3573,141.15 and 143.23) studied is L-Lys-Gly ${ }_{4-5}$, L-Ser $_{0.8-1.2}$. The cell wall teichoic acids of these strains are composed of glycerol, $\mathrm{N}$-acetylglucosamine, and small amounts of glucose.

All strains are susceptible to novobiocin (MIC, $0.1 \mu \mathrm{g} / \mathrm{ml}$ ), penicillin G (MIC, $\leqslant 0.06$ $\mu \mathrm{g} / \mathrm{ml}$, with one exception; strain 141.15 has a penicillin G MIC of $0.5 \mu \mathrm{g} / \mathrm{ml}$ ), tetracycline hydrochloride (MIC, $\leqslant 0.5 \mu \mathrm{g} / \mathrm{ml}$ ), erythromycin (MIC, $\leqslant 0.5 \mu \mathrm{g} / \mathrm{ml}$ ), lincomycin (MIC, $\leqslant 1$ $\mu \mathrm{g} / \mathrm{ml}$ ), streptomycin (MIC, $\leqslant 16 \mu \mathrm{g} / \mathrm{ml}$ ), neomycin ( $\mathrm{MIC}, \leqslant 1 \mu \mathrm{g} / \mathrm{ml}$ ), furazolidone (MIC, $\leqslant 8$ $\mu \mathrm{g} / \mathrm{ml}$ ), and sulfamethoxazole (MIC, 4 to 8 $\mu \mathrm{g} / \mathrm{ml}$ ).

The strains are resistant to lysozyme (MIC, $>800 \mu \mathrm{g} / \mathrm{ml}$.

The lysostaphin MIC is 128 to $256 \mu \mathrm{g} / \mathrm{ml}$.

The results of DNA-DNA hybridization studies indicate the phylogenetic relationships to other staphylococci, in particular the relationships to $S$. capitis and $S$. epidermidis (Table 2).

Characteristics that differentiate $S$. caprae from other coagulase-negative staphylococci are shown in Table 3. In particular, the unique fermentation pattern of $S$. caprae with its negative mannitol, fructose, and sucrose reactions is useful in the identification of this species.

Strain $143.22(=$ CCM 3573$)$ is designated the type strain of $S$. caprae. This strain was isolated from a milk sample taken from a goat, and its characteristics are described below.

Strain $143.22^{\mathrm{T}}$ cells are nonmotile, nonsporeforming, gram-positive cocci that occur in pairs or singly in groups or short chains. The cell diameter is 0.8 to $1 \mu \mathrm{m}$.

Strain $143.22^{1}$ colonies are circular with entire edges, low convex, opaque, nonpigmented, and glistening, with diameters ranging from 2 to 6 $\mathrm{mm}$. Facultatively anaerobic. Grows better at 37 to $45^{\circ} \mathrm{C}$ than at 25 to $30^{\circ} \mathrm{C}$. Positive for catalase, phosphatase, acetoin, nitrate, and arginine and negative for coagulase, clumping factor, oxidase, protease, hyaluronidase, staphylokinase, urease, polysorbate (Tween 80), and esculin. Hemolytic on human blood agar. Produces a double hemolysis zone after 2 days on sheep blood agar. Heat-labile nuclease positive; heatstable nuclease negative.

Produces acid from galactose, lactose, glycerol, mannose, and trehalose, No acid is produced from amygdalin, arabinose, arbutin, cellobiose, fructose, fucose, $\beta$-gentiobiose, maltose, mannitol, melezitose, melibiose, raffinose, rhamnose, ribose, salicin, sucrose, sorbitol, turanose, xylitol, or xylose.

Susceptible to novobiocin, penicillin G, tetracycline hydrochloride, erythromycin, lincomycin, chloramphenicol, streptomycin, neomycin, furazolidone, and sulfamethoxazole.

Lysostaphin MIC: $128 \mu \mathrm{g} / \mathrm{ml}$. Resistant to lysozome.

Class I fructose 1,6-diphosphate aldolase.

Peptidoglycan type: L-Lys-Gly 4.2, L-Ser 0.9 .

Composition of cell wall teichoic acid: glycerol, $\mathrm{N}$-acetylglucosamine, and small amounts of glucose. 
TABLE 3. Characteristics useful in differentiating $S$. caprae from other coagulase-negative Staphylococcus species which are susceptible to novobiocin ${ }^{a}$

\begin{tabular}{|c|c|c|c|c|c|c|c|c|}
\hline Test & $\begin{array}{l}\text { S. cap- } \\
\text { rae }\end{array}$ & $\begin{array}{l}\text { S. epider- } \\
\text { midis }\end{array}$ & $\begin{array}{l}\text { S. capi- } \\
\text { tis }\end{array}$ & $\begin{array}{l}\text { S. haemo- } \\
\text { lyticus }\end{array}$ & $\begin{array}{l}\text { S. war- } \\
\text { neri }\end{array}$ & $\begin{array}{l}\text { S. sim- } \\
\text { ulans }\end{array}$ & $\begin{array}{l}\text { S. hyicus } \\
\text { subsp. } \\
\text { hyicus }\end{array}$ & $\begin{array}{l}\text { S. hyicus } \\
\text { subsp. } \\
\text { chromo- } \\
\text { genes }\end{array}$ \\
\hline Pigment & $-b$ & - & - & $\mathrm{D}$ & D & - & - & $\mathrm{D}$ \\
\hline Heat-stable deoxyribonuclease & - & - & - & - & - & - & + & w \\
\hline $\begin{array}{l}\text { Hemolysis on sheep blood } \\
\text { agar ( } 2 \text { days) }\end{array}$ & + & - or $w$ & - or w & + & w or - & - or $w$ & - & - \\
\hline Phosphatase & + & + & D- & - & $\mathrm{D}-$ & - or $\mathrm{w}$ & + & + \\
\hline Hyaluronidase & - & - & - & - & - & - & + & - \\
\hline Tween 80 & - & - or $w$ & - & - & - or w & - or $\mathrm{w}$ & + & - \\
\hline Fructose & - & + & + & $+(\text { or } \mathrm{D})^{c}$ & + & + & + & + \\
\hline Maltose & $D+$ & + & - & + & $\mathrm{D}+$ & - & - & $\mathrm{D}$ \\
\hline Mannose & + & $\mathrm{D}+$ & $\mathrm{D}+$ & - & $D(-)$ & D & + & + \\
\hline Ribose & - & $+(-)$ & - & D & $\mathrm{D}+$ & $\mathrm{D}$ & + & + \\
\hline Trehalose & + & - & - & + & + & + & $+d$ & + \\
\hline Sucrose & - & + & $\mathrm{D}+$ & + & + & + & + & + \\
\hline Turanose & - & $\mathrm{D}$ & - & + & D & D & - & $\mathrm{D}$ \\
\hline $\begin{array}{l}\text { Lysostaphin } \\
\mathrm{MIC} \geq 100 \mu \mathrm{g} / \mathrm{ml}\end{array}$ & + & + & + & D & + & - & - & - \\
\hline
\end{tabular}

${ }^{a}$ Some $S$. hyicus subsp. hyicus strains are coagulase positive.

$b+$, More than $90 \%$ of the strains are positive; - , more than $90 \%$ of the strains are negative; D, between 25 and $75 \%$ of the strains are positive; $\mathrm{D}+$, more than $75 \%$ but less than $90 \%$ of the strains are positive; $\mathrm{D}-$, more than $75 \%$ but less than $90 \%$ of the strains are negative; w, weak reactions.

${ }^{c}$ The results in parentheses are from the study of Kloos and Schleifer (19) and were obtained by using purple agar; the other results were obtained by using phenol red broth (7) supplemented with carbohydrates.

${ }^{d}$ Bovine strains are often trehalose negative.

Guanine-plus-cytosine content of DNA: 36.1 mol\% (thermal denaturation method).

\section{LITERATURE CITED}

1. Adegoke, G. O. 1981. Characterization of staphylococci isolated from goats. I. Coagulase activities and antibiotic susceptibility patterns. Zentralbl. Bakteriol. Parasitenkd. Infektionskr. Hyg. Abt. 1 Orig. Reihe A 249:431-437.

2. Adegoke, G. O., and M. O. Ojo. 1981. Characterization of staphylococci isolated from goats. II. Differentiation from human strains: fibrinolysin and beta-haemolysin production. Zentralbl. Bakteriol. Parasitenkd. Infektionskr. Hyg. Abt. 1 Orig. Reihe A 249:438-442.

3. Bornstein, N., and J. Fleurette. 1981. Acetoin production in the identification of isolates as members of Staphylococcus intermedius Hájek. Int. J. Syst. Bacteriol. 31:232235.

4. Curry, J. C., and G. E. Borovian. 1976. Selective medium for distinguishing micrococci from staphylococci in the clinical laboratory. J. Clin. Microbiol. 4:455-457.

5. Davis, G. H. G., and B. Hoyling. 1973. Use of a rapid acetoin test in the identification of staphylococci and micrococci. Int. J. Syst. Bacteriol. 23:281-282.

6. Devriese, L. A. 1977. Isolation and identification of Staphylococcus hyicus. Am. J. Vet. Res. 38:787-792.

7. Devriese, L. A. 1979 . Identification of clumping factornegative staphylococci isolated from cows' udders. Res. Vet. Sci. 27:313-320.

8. Devriese, L. A., V. Hájek, P. Oeding, S. A. Meyer, and H. K. Schleifer. 1978. Staphylococcus hyicus (Sompolinsky 1953) comb. nov, and Staphylococcus hyicus subsp. chromogenes subsp. nov. Int. J. Syst. Bacteriol. 28:482-490.

9. Devriese, L. A., and A. Van de Kerckhove. 1979. A comparison of methods and the validity of deoxyribonuclease tests for the characterization of staphylococci isolated from animals. J. Appl. Bacteriol. 46:385-393.
10. Devriese, L. A., and A. Van de Kerckhove. 1980. A comparison of methods used for testing staphylokinase (fibrinolysin) production in Staphylococcus strains. Antonie van Leeuwenhoek J. Microbiol. Serol. 46:457-465.

11. Evans, J. B., and W. E. Kloos. 1972. Use of shake cultures in a semisolid thioglycollate medium for differentiating staphylococci from micrococci. Appl. Microbiol. 23:326-331.

12. Faller, A., and K. H. Schleifer. 1981. Modified oxidase and benzidine tests for separation of staphylococci. $J$. Clin. Microbiol. 13:1031-1035.

13. Frazier, W. C. 1926. A method for detecting changes in gelatin due to bacteria. J. Infect. Dis. 39:302-309.

14. Götz, F., E. Nürnberger, and K. H. Schleifer. 1979. Distribution of class I and class II D-fructose-1,6-biphosphate aldolase in various gram-positive bacteria. FEMS Microbiol. Lett. 5:253-257.

15. Hájek, V. 1976. Staphylococcus intermedius, a new species isolated from animals. Int. J. Syst. Bacteriol. 26:401408.

16. Kilpper, R., U. Buhl, and K. H. Schleifer. 1980. Nucleic acid homology studies between Peptococcus saccharolyticus and various anaerobic and facultative anaerobic Gram-positive cocci. FEMS Microbiol. Lett. 8:205-210.

17. Kilpper-Bälz, R., and K. H. Schleifer. 1981. Transfer of Peptococcus saccharolyticus Foubert and Douglas to the genus Staphylococcus: Staphylococcus saccharolyticus (Foubert and Douglas) comb. nov. Zentralbl. Bakteriol. Parasitenkd. Infektionskr. Hyg. Abt. 1 Orig. Reihe C 2:324-331.

18. Kloos, W. E., and K. H. Schleifer. 1975. Isolation and characterization of staphylococci from human skin. II. Descriptions of four new species: Staphylococcus warneri, Staphylococcus hominis, and Staphylococcus simulans. Int. J. Syst. Bacteriol. 25:62-79.

19. Kloos, W. E., and K. H. Schleifer. 1975. Simplified scheme for routine identification of human Staphylococcus species. J. Clin. Microbiol. 1:82-88. 
20. Kloos, W. E., K. H. Schleifer, and R. F. Smith. 1976. Characterization of Staphylococcus sciuri sp. nov. and its subspecies. Int. J. Syst. Bacteriol. 26:22-37.

21. Kloos, W. E., R. J. Zimmerman, and R. F. Smith. 1976. Preliminary studies on the characterization and distribution of Staphylococcus and Micrococcus species on animal skin. Appl. Environ. Microbiol. 31:53-59.

22. Lautrop, H. 1960. Laboratory diagnosis of whoopingcough or Bordetella infections. Bull. W.H.O. 23:15-31.

23. Marmur, J., and P. Doty. 1962. Determination of the base composition of deoxyribonucleic acid from its thermal denaturation temperature. J. Mol. Biol. 5:109-118.

24. Schleifer, K. H., and U. Fischer. 1982. Description of a new species of the genus Staphylococcus: Staphylococcus carnosus. Int. J. Syst. Bacteriol. 32:153-156.

25. Schleifer, K. H., and O. Kandler. 1970. Amino acid sequence of the murein of Planococcus and other Micrococcaceae. J. Bacteriol. 103:387-392.

26. Schleifer, K. H., and O. Kandler. 1972. Peptidoglycan types of bacterial cell walls and their taxonomic implications. Bacteriol. Rev. 32:407-477.

27. Schleifer, K. H., R. Kilpper-Bälz, U. Fischer, A. Faller, and J. Endl. 1982. Identification of "Micrococcus candi- dus" ATCC 14852 as a strain of Staphylococcus epidermidis and of "Micrococcus caseolyticus" ATCC 13548 and Micrococcus varians ATCC 29750 as members of a new species, Staphylococcus caseolyticus. Int. J. Syst. Bacteriol. 32:15-20.

28. Schleifer, K. H., and W. E. Kloos. 1975. Isolation and characterization of staphylococci from human skin. I. Amended description of Staphylococcus epidermidis and Staphylococcus saprophyticus and descriptions of three new species: Staphylococcus cohnii, Staphylococcus haemolyticus, and Staphylococcus xylosis. Int. J. Syst. Bacteriol. 25:50-61.

29. Schleifer, K. H., and M. Kocur. 1973. Classification of staphylococci based on chemical and biochemical properties. Arch. Mikrobiol. 93:65-85.

30. Schleifer, K. H., S. A. Meyer, and M. Rupprecht. 1979. Relatedness among coagulase-negative staphylococci. Deoxyribonucleic acid reassociation and comparative immunological studies. Arch. Microbiol. 122:93-101.

31. von Rheinbaben, K. E., and R. M. Hadlok. 1981. Rapid distinction between staphylococci and micrococci with furazolidone agars. Antonie van Leeuwenhoek J. Microbiol. Serol. 47:41-51. 